\title{
Kerkreg? Die plek van Kerkreg en Kerkregering
}

\author{
Barry J van Wyk ${ }^{1}$ \\ Hervormde Teologiese Kollege \\ Universiteit van Pretoria
}

\begin{abstract}
Church polity? The position of church polity and church government

It is generally accepted that John Calvin can be referred to as the founder of the presbyterial-synodal form of church government which is found in the Reformed Churches. It would therefore be appropriate to focus on his views and to indicate to what extent he influenced the notion that Jesus Christ is Head of the Church and Lord of the world. If it can once again be concluded that there is a close relation between Church, Confession and Church Ordinance, then it is quite evident that Church polity occupies a fundamental place in the Reformed Churches which must be treated with greater concern.
\end{abstract}

\section{INLEIDING}

Die opskrif van meegaande artikel verraai 'n bepaalde besorgdheid met betrekking tot die plek en die bruikbaarheid van Kerkreg as teologiese wetenskap wat aan teologiese fakulteite doseer word met die oog op die vorming van toekomstige bedienaars van die Woord. Behalwe die opleiding van studente moet ook die vraag gestel word na die hedendaagse bruikbaarheid van Kerkreg in kerke en gemeentes. In die opleiding van studente van die Nederduitsch Hervormde Kerk van Afrika word slegs twaalf lesings deur die Hervormde Teologiese Kollege (HTK) beskikbaar gestel waarin studente van die eie Kerk vertroud gemaak moet word met die bepaalde klemtone wat op die Reformatoriese Kerkreg in die Hervormde Kerk gelê word (Storm 2007:1). Daarbenewens bestaan daar sedert die samesmelting van die twee teologiese fakulteite van die Nederduitse Gereformeerde Kerk en die Nederduitsch Hervormde Kerk van Afrika aan die Universiteit van Pretoria, nie 'n voltydse dosent wat die leerstoel

${ }^{1}$ Lesing gehou voor die Kerkregwerkgemeenskap van Suid-Afrika, Pretoria 25 Julie 2006. 


\section{Kerkreg? Die plek van Kerkreg en Kerkregering}

Kerkgeskiedenis en Kerkreg hanteer soos tradisioneel die gebruik was tot en met bogenoemde samesmelting nie.

Die blote feit dat die Kerkreg Werkgemeenskap wat bestaan uit teoloë van die Nederduitse Gereformeerde Kerk, Gereformeerde Kerk in Suid-Afrika, asook die Nederduitsch Hervormde Kerk van Afrika op sy vergadering in Potchefstroom op 6 en 7 September 2005 besluit het op bogenoemde tema vir 2006, toon aan dat 'n bepaalde besorgdheid ten minste in al drie laasgenoemde kerke beleef word. 'n Redelike aanduiding waarom Kerkreg, of nader bepaald Reformatoriese of Gereformeerde Kerkreg belangriker is as wat moontlik vermoed word, sal noodwendig van die oorsprong en wording kennis moet neem as aanduiding waarom groter erns en meer toegewyde aanwending van die Kerkreg in kerk en gemeente, tot die wel-wese van beide kan bydra.

\section{HISTORIESE AGTERGROND MET BESONDERE VERWYSING NA JOHANNES CALVYN (1509-1564)}

Dit word redelik algemeen aanvaar dat die oorspronge van die Reformatoriese of Gereformeerde Kerkreg terug gevoer kan word na die kerkvormende arbeid van die geniale hervormer Johannes Calvyn (15091564). Hy het anders as Luther (1483-1546) raakgesien dat daar 'n verband bestaan tussen die kerkregtelike struktuur waarbinne die kerk sigself sien en die geloof wat die kerk bely. "Dit is eers Johannes Calvyn, die geniale hervormer van die tweede generasie, wat duidelik besef dat die kerklike orde van die hervormde kerk net so belangrik is as die hervormde leer. Die kerk is en moet immers die draer wees van die ware evangelie en om daardie taak reg te kan doen, moet die kerk ook 'n regte organisasie of struktuur hê" (Pont 1981:3). Die wye aanvaarding dat Calvyn die vader van die presbiteriaalsinodale stelsel van kerkregering genoem kan word is vanweë sy wesenlike invloed wat veral uit verskeie kerkordes blyk (kyk Oostenbrink-Evers 2000:22; Nauta 1960:502-503; Plomp 1971:110; Haitjema 1925:183 vv; Van 't Spijker 1990:326-338; Smit 1984:59; Milner 1970; Coertzen 1991:22 vv en Van Wyk 1989: 5-6). Sy kerkordende maatreëls sien daarom die lig enersyds in Genève met sy Ordonnances Ecclésiastique 1541/1561 wat hoofsaaklik 'n kerkorde was vir die enkele gemeente in Genève. Die bedoeling is nie om hiermee te stel dat hy alleen verantwoordelik was vir die Geneefse Kerkorde nie maar dat sy invloed besonder sterk gegeld het. Plomp stel dit soos volg:

Het concept, door Calvijn zelf geschreven, bevindt zich in het archief van de stad Genève. In margine en in de tekst zijn toevoegingen aangebracht, zinnen geschrapt en uitdrukkingen vervangen, door een andere hand: die van de man die in die tijd 
gewoonlijk de notulen van de raadsvergaderingen verzorgde, secretaris Pierre Ruffi.

(Plomp 1969: 166)

Die invloed van Calvyn geld ook in die Discipline Ecclésiastique 1559 as die Kerkorde wat in Parys die lig sien en anders as Genève 'n kerkorde daarstel waarby meer as een gemeente betrokke is. "Hier word dus 'n orde geskep wat ál die gemeentes saamvat in één, geordende geheel en waar die geestelike regering van Jesus Christus, die Heer van die kerk, deur middel van sy diensknegte, die ampsdraers uitgespel word" (Pont 1981:48). Dit word 'n kerkorde wat saamgestel word om twee en sewentig gemeentes te bedien in tye waarin die kerk onder groot spanning verkeer het soos blyk uit die volgende uitspraak: "[i]s de ware Kerk kenbaar aan het klokgelui, de valse Kerk aan de schoten van haakbussen en pistolen, zeiden de tegenstanders" (Bakhuizen van den Brink 1962:81).

As dit algemeen toegegee word dat Calvyn die grondlegger is van wat in Reformatoriese kerke aangetref word as die presbiteriaal-sinodale stelsel van kerkregering, is dit waarskynlik dienlik om homself aan die woord te stel oor die orde van die kerk. Oor die bekende Pauliniese teks (1 Kor 14:40) waar die woord orde (taksis) gebruik word en wat in kerkregtelike literatuur selfs as locus classicus uitgesonder word (Smit 1989:6), lewer hy die volgende kommentaar:

De Heere heeft de uitwendige gebruiken daarom in onze vrijheid gelaten, opdat wij niet souden denken, dat zijn dienst daarin besloten is: toch heeft Hij ons geene ongestadige en ongebodene vrijheid toegelaten, maar Hij heeft (om alzoo te spreken) traliën daarom gesteld, of althans de vrijheid, die Hij gegeven had, zóó gematigd, dat men eerst uit zijn Woord moet waardeeren wat recht is.

(Calvyn 1972:248)

Die feit dat die Woord van God bepalend is vir die orde van die kerk blyk ook uit uitsprake in die Institusie. Hy verwys na bogenoemde teks en sê "[a]s ons daarom die welstand van die kerk in ag wil neem, moet ons met alle deeglikheid sorg dat alles daarin betaamlik en ordelik moet geskied soos Paulus ons beveel" (Calvyn 1992:1494). Die Skriftuurlike uitgangspunt beperk kerklike orde en mag wat ampsdraers meen om oor te beskik, en daarom stel Calvyn dat hy "slegs daardie menslike instellings goedkeur wat sowel op God 


\title{
Kerkreg? Die plek van Kerkreg en Kerkregering
}

se gesag gegrond as aan die Skrif ontleen is en wat daarom Goddelik is" (Calvyn 1992:1497). Die orde van die kerk is daarom van besondere aard en behoort daarop uit te loop dat Hy alleen in die kerk regeer. "Hy alleen behoort aan die hoof daarvan te wees en daarin op die voorgrond te staan en hierdie regering behoort volgens sy Woord alleen beoefen en bestuur te word" (Calvyn 1992:1317).

Daarom bestaan Calvyn se besondere kerkregtelike bydrae veral daarin dat hy 'n belydende verband gelê het tussen die Woord van God en die kerklike orde. Noordmans verwoord dieselfde uitgangspunt met die volgende stelling: "[m]its de eis van kerkelijke denken, dat er verband is tussen belijdenis en organisatie, word vastgehouden. Ik heb vroeger geschreven dat de kerkorde niet met dezelfde geestelijke macht uit de Schrift wordt afgeleid als het sola fide. Maar de afleiding uit de bijbel dient vastgehouden" (Noordmans 1984:444). Dieselfde Noordmans het die kerkregtelike bydrae van Calvyn met behulp van die skaakbord verduidelik met sy stelling: "[t]oen Calvijn op het bord de pion van de ouderling trok, zette hij daarmee de paus schaakmat" (Noordmans 1984:396).

\section{VERDERE KERKREGTELIKE VERLOOP}

Die bruikbaarheid van Calvyn se insette bly nie beperk tot Genève en Parys nie, maar beïnvloed en bepaal tot 'n groot mate die kerkregtelike ontwikkeling wat op Nederlandse bodem ontstaan soos blyk uit die kerkordes wat sedert Emden 1571 tot Dordt 1618-19 vasgestel word. Hoewel Haitjema (1925) en De Jongh (1911), onder andere, nie noodwendig saamstem nie blyk uit hulle argumente samevattend dat die invloed van Calvyn beduidend was in die kerkregtelike ontwikkeling van Nederland. Pont (1981:71) sluit hierby aan wanneer hy sê:

\begin{abstract}
Enersyds is daar die invloed van die Londense kerkorde met alles wat daarmee saamhang, en andersyds is daar die invloed van Johannes Calvyn se Geneefse Ordonnances Ecclésiastiques en daarmee weer samehangende die Franse presbiteriaal-sinodale kerkorde van 1559 en die Waalse kerkordende reëlings van 15631566.
\end{abstract}

Coertzen (1991:26 vv) bevestig ook dat talle Gereformeerde teoloë in die voetspore van Calvyn gevolg het en verwys op Nederlandse bodem na figure soos Voetius (1589-1676), en ná die Afskeiding en Doleansie na Kuyper, Rutgers en Haitjema. Hier kan ook die naam van Hoedemaker bygevoeg word. Die agtergronde van die kerkregtelike denke van die drie genoemde 
kerke in Suid-Afrika kan vanuit die Nederlandse kerkregtelike ontwikkeling verstaan word na aanleiding van die Reformasie met besondere verwysing na Calvyn.

\section{DIE KERKBEGRIP: PRESBITERIAAL-SINODAAL}

Behalwe die duidelik Skriftuurlike verband tussen die Skrif en die kerklike organisasie het uit die kerkregtelike denke van Calvyn die presbiteriaalsinodale stelsel van kerkregering te voorskyn gekom wat kenmerkend is van kerke in Reformatoriese of Gereformeerde tradisie. Vir duidelikheid is dit nodig om kortliks aan te dui wat die dubbelbegrip in kerkregtelike verband behels. Wesenlik gaan dit hier oor die presbiteriaal-sinodale kerkbegrip, of die manier hoe die kerk homself in ekklesiologiese verband sien.

Presbiteriaal-sinodaal beteken eerstens dat Jesus Christus Hoof van die kerk en Heer van die wêreld is (Pont 1981:192; Post 2003:23; Oostenbrink-Evers 2000:22; Van der Walt 1976:53; Van der Linde 1965:82; Van den Heuvel 2004:41; Kleynhans 1982:80; Spoelstra 1989:26 en Coertzen 1991 :86). Dit ten spyte van die feit dat daar in die kerkregtelike ontwikkeling bepaalde modaliteite en variante bestaan, en soms slegs van presbiteriale kerkregering gepraat word (Van der Linde1965; Van der Walt 1976; kyk ook Van der Linde 1971).

Tweedens kom dit daarop neer dat Christus sy kerk onmiddellik regeer deur Woord en Gees, en daarnaas middellik deur ampsdraers wat ter vergadering kom om gesamentlik besluite te neem onder leiding van die Gees van God, op grond van Woord, belydenis en kerklike orde (Botha 1995:768). Volgens artikel 30 van die Nederlandse Geloofsbelydenis beteken dit dat Christus sy kerk wil regeer en lei deur dienaars van die Woord, ouderlinge en diakens. Ampsdraers het geen gesag as sodanig nie, maar alleen gesag wanneer God deur hulle dienswerk aan die woord kom. Daarom is die amp nie 'n hoë posisie (officium) nie, maar 'n nederige dienswerk (ministerium) (Calvyn 1992:1318) waar iemand slegs ampsdraer kan wees wanneer hy funksioneel die ampswerk verrig wat eie aan die amp is. Verder is daar 'n belangrike voorwaarde aan die amp verbonde naamlik, dat iemand 'n geroepe ampsdraer moet wees. Calvyn (1992:1326) gebruik Paulus as voorbeeld: "[w]anneer hy goedkeuring vir sy apostelskap wil verkry, verwys hy feitlik altyd na sy roeping saam met sy getrouheid in die uitvoering van sy amp." Hy onderskei roeping ook in 'n innerlike roeping waarvan elkeen voor God bewus is en die kerk nie as getuie het nie, en uiterlike roeping wat op die openbare orde van die kerk gerig is (Calvyn:1992:1327). 


\section{Kerkreg? Die plek van Kerkreg en Kerkregering}

Derdens oefen geroepe ampsdraers hulle roeping uit in die kerk maar veral wanneer hulle in vergaderings byeenkom om die kerk te regeer. Die mees primêre vergadering is die vergadering van die kerkraad in elke gemeente waar ampsdraers hulle roeping ten uitvoer bring binne die ruimte van die gemeente as die plaaslike en normale verskyningsvorm van die kerk (Pont 1981:221). Dit is immers in die plaaslike gemeente waar die Woord verkondig, die sakramente bedien en die kerklike dissipline aan die orde kom. Elke bedienaar van die Woord sal hierin die sogenaamde notae ecclesiae van Calvyn herken (Calvyn 1992:1280). Die bestaan van meer as een gemeente naas mekaar het noodwendig vergaderings van die ampte die lig laat sien wat saamgestel is uit ampsdraers van meer as een gemeente. Hierdie meerdere of bykomende vergaderings het na vore gekom omdat gemeentes nie alle sake alleen kon afhandel nie, en ook omdat daar sake van gemeenskaplike belang ter sprake gekom het wat nie net een gemeente raak nie (Plomp 1971:91).

As gevolg van die verbreiding van die kerk het naas klassikale- of ringsvergaderings ook provinsiale- en nasionale sinodes tot stand gekom wat almal as organe van bystand vir die plaaslike gemeente beskou kan word, sodat die gemeente die kerk se werk nog beter kan doen (Kersten 1980:183187). Hier kom ook na 1816 die sinodale kommissie na vore (Hooijer 1846:4146) wat sedertdien 'n redelik permanente verskyningsvorm in die kerklike lewe geword het. Dit was deel van die ordelike samestelling van meerdere vergaderings dat slegs die sake hanteer word wat aan elke vergadering opgedra is. Daar is dus nie oor alle sake gepraat nie, in elke geval nie wat deur mindere vergaderings afgehandel kan word nie (Kersten 1980:183, Artikel $X X X)$. Die verhouding tussen plaaslike gemeente en sinode het een van die mees brandende kwessies in kerkregtelike sin gebly tot op hede. Soms word die gemeente swaarder beklemtoon en andersyds raak sinodes en hulle kommissies nie maklik gewoond aan die gesag wat hulle meen om oor te beskik nie. Die argument wat waarskynlik die ewewig die beste kan bewaar is om te aanvaar dat Jesus Christus Hoof van die kerk en Heer van die wêreld is en dat beide, sinode en gemeente, niks meer kan doen nie as om dienend die Christus regering voorrang te laat geniet en dat die Gees van God eweneens in die plaaslike gemeente as in die sinodale vergadering spreek. Noordmans se waarskuwing dat dit 'n erfsonde van die kerk is om te meen dat hy oor die Gees beskik is hier waarskynlik op sy plek (Noordmans 1990:390). Die gesag van sinodale vergaderings kom tot uiting in die mate waarin die gesag van die Woord daarin sigbaar word (Calvyn 1992:1454; Spoelstra 1989:268). Die volgende opmerking van Calvyn met betrekking tot ouer sinodes soos Nicéa onder andere, verwoord sy uitgangspunt: 
Ons omhels met graagte die sinodes van ouds soos die van Nicéa, Konstantinopel, die eerste sinode van Efese, Chalcedon en dergelikes wat belê is om dwalings te weerlê, en ons eerbiedig dit as heilige vergaderings so ver dit leerstellings van die geloof aangaan. Hulle bevat immers niks anders as 'n suiwer en egte vertolking van die Skrif wat die heilige vaders met geestelike wysheid aangewend het om die vyande van die godsdiens wat destyds na vore getree het, te verbrysel nie.

(Calvyn 1992:1454)

Vierdens word gehandel oor die leer, sakramente en ander seremonies. Naas Calvyn se kerkordelike denke soos verwoord in die kerkordes wat met sy hulp die lig gesien het, beywer hy hom ook om geloofsbelydenisse op te stel. Daarvan is die Hugenote Belydenis of Confessio Gallicana 1559, die Geneefse Kategismus 1545 en die Geneefse Belydenis 1536 sprekende voorbeelde (Müller 1903).

Die klem op belydenis en belydenisskrifte verteenwoordig dus die middelbegrip van die drie wat as Skrif, belydenis en kerklike orde genoem kan word en dui ' $n$ onderliggende relasie aan wat eie is aan presbiteriaal-sinodaal. Die Reformatoriese kerkreg soos verwoord in die denke van Calvyn as die grondlegger van die stelsel waar erns gemaak word met die Hoof en Heerskap van Christus, maak groot erns met die belydenis as die getuienis wat noue omgang met die Skrif voortbring en kerklike handelinge en belydenis aan mekaar bind. Daarom onderteken proponente die proponentsformule by toelating onder die quia-uitgangspunt, waardeur die belydenisskrifte van die kerk, onder andere, eietyds gemaak word. Verder is ook hieronder ingesluit die twee sakramente Doop en Nagmaal, asook eredienste en buitengewone eredienste en liturgie (Kersten 1980:187-191).

Die laaste twee komponente wat hierby gevoeg kan word is kerklike dissipline en die verhouding tussen kerk en owerheid. Meesal word met betrekking tot die notae ecclesiae na die kerklike dissipline verwys as die derde merkteken, moontlik op voetspoor van Artikel 29 van die Nederlandse Geloofsbelydenis, terwyl Calvyn slegs na die eerste twee verwys wanneer hy die saak in sy Institusie ter sprake bring (Calvyn 1992:1280). Plomp gee daarvoor 'n verklaring wat daarop neerkom dat hy die kerklike dissipline slegs sien as die bene esse van die kerk en daarom, ook vanweë die kerklike klimaat van sy tyd, die onderskeid tref (Plomp 1969:124). Nietemin kom sy erns met die saak wel in die Institusie ter sprake (Calvyn 1992:1522 e v) soos verder onder andere ook blyk uit 'n brief aan Farel van 16 September 1541, 


\section{Kerkreg? Die plek van Kerkreg en Kerkregering}

asook in sy verweerskrif aan Sadoletus op 1 September 1539 (Reid 1965:232; Van Wyk 2004:130-131).

Calvyn wy die laaste hoofstuk van sy Institusie aan die verhouding kerk en owerheid. Naas die positiewe wat met die kerkregtelike denke van Calvyn ervaar word soos dit later ook in Nederlandse konteks gevind word, moet daarop gewys word dat nooit werklik daarin geslaag is om van die invloed van die owerheid in kerklike sake ontslae te raak nie. Cotrett (2005:172) maak die volgende opmerking:

Genève heeft nooit een theocratie gevormd. Niet alleen blijven de geestelijke en tijdelike macht onderscheiden, niet alleen bestuurt Calvijn de stad niet, maar de reformator moet stap voor stap de onafhankelijkheid van de besluiten van de kerk bevechten tegenover de inbreuken door de Raad.

\section{MENINGS OOR WAT ONDER KERKREG VERSTAAN WORD}

Na die poging tot omlyning van die gangbare kerkregtelike stelsel as gevolg van die Reformasie kom die vraag na vore: wat is Kerkreg? Minstens moet vooraf gestel word dat kerkreg nie een of ander faset van burgerlike wetgewing in profane gewaad is wat die kerk se interne aangeleenthede wil reël op die basis van maar net nog 'n vrywillige vereniging in die samelewing nie. Juis dit maak die wetgewing op arbeidsverhoudinge vir sommige, veral die wat met die kerk oor een of ander saak ontevrede raak of onder die indruk verkeer dat kerklike maatreëls agterhaal is, besonder aanloklik.

Kerkreg beleef in die huidige konteks dikwels teenstand van sommiges aangesien die argument gebruik word dat die huidige mens in die sogenaamde post-moderne era leef wat nie voorgeskryf of wie se lewe nie gereglementeer moet word nie. Die handhawing van kerkregtelike uitgangspunte mag dus die indruk skep dat hier gewerk word met 'n beklemtoning van sogenaamde absolute en totalitêre waarheidsaansprake wat derhalwe gedekonstrueer moet word (kyk Dreyer 2006:1312). Die reaksie hierop is die mening dat dit relativisme tot gevolg het waar elkeen maak soos hy dit goed vind.

Verskillende persone het in die verlede oor die kerklike reg nagedink en bepaalde definisies van wat hulle meen Kerkreg is geformuleer. Barth (1964:772) definieer kerkreg soos volg: "Rechtes Kirchenrecht entsteht (in grossen und kleinen, in allen Dingen!) aus dem Hören auf die Stimme Jesu Christi." Coertzen (1991:159) vermeld een van die vroegste definisies van 
Kerkreg soos die teruggevind word by Voetius (1663-1676), naamlik: scientia sacra regendi ecclesiam visibilem. Spoelstra (1989:8) sê dat "die regering (koninkryk) wat Jesus Christus uitoefen, kerkreg vir die volk van die Koning bepaal. In die teologie moet die vak Kerkreg hierdie reg wat die Koning in die Skrif gegee het, naspeur". Smit (1984:70-71) verwoord dit op die volgende wyse: "So gesien is kerkreg die navorsing en die handhawing van wat vir God goed en reg is vir sy herstelde volk oor wie Christus die Koningsheerskappy voer." Hy meld verder dat Spoelstra en Van der Linde die kerkreg in die juiste perspektief plaas as synde die skrifbeginsels vir ware kerkwees en kerkregering, en meld verder dat kerkreg as wetenskap die dissipline is wat "die beginsels vir die instituering, die organisasie en die regering van die kerk, sowel as die gedrag van die kerk uit die Heilige Skrif navors" (kyk ook Bouwman 1985:10 vv). Ook Bouwman laat daaroor geen twyfel dat kerkreg 'n teologiese wetenskap is "omdat het tot inhoud heeft het recht, dat in de kerk geldt en gelden moet volgens de H. Schrift." Hy vervolg daarop met

De kerk heeft een eigen leven en daarom een eigen recht, dat rust op het recht, door Christus, den Koning der kerk, gegeven. Zij behoeft niet door de overheid te worden erkend, om als kerk op te treden. Zij is er krachtens van Christus en het leven des Geestes, die in haar woont. Daarom is elk pogen, om het kerkrecht op grond van het natuurrecht of het vereenigingsrecht te construeeren, verkeerd te noemen.

(Bouwman 1985:13)

Van de Beek ([1988]:71) se definisie van kerkreg lui soos volg:

Kerkrecht is daarbij die teologische wetenschap, die in de complexiteit van het theologische gebeuren in het bijzonder aandacht heeft voor de functie van de vastgelegde rechtsregels, in samehang met het geheel van de bezinning op de betekenis van het evangelie in de wereld waarvan de kerk zelf een onderdeel is.

Die onderskeid kerkreg en kerkregering word veral in Gereformeerde kringe gebruik en hier word met een definisie volstaan:

Dit is belangrik dat die twee begrippe [kerkreg en kerkregering] duidelik begryp moet word, beide in hulle uniekheid en onderlinge korrelasie. Kerkreg is die wetenskap wat nadink oor wat die Skrif vir ons leer oor die orde vir die kerk van Christus, wat die gang van die orde deur die geskiedenis heen naspoor en wat wil help om die 


\section{Kerkreg? Die plek van Kerkreg en Kerkregering}

orde vir die kerk ook tot 'n orde in die kerk te maak. Kerkregering is die praktyk van elke dag se kerkwees waarin gestalte, uitvoering, aan die resultate van kerkreg as wetenskap gegee word.

(Coertzen 1991:xi; kyk ook Spoelstra 1989)

Dit is opvallend dat in bogenoemde menings oor wat onder Kerkreg verstaan moet word deurgaans die Woord van God as norm en rigsnoer vir die kerklike lewe ter sprake kom. Die houdbaarheid van Kerkreg as sodanig, as teologiese wetenskap of as rigsnoer vir die kerklike lewe in kerke en gemeentes, staan en val op grond van die Skriftuurlike bepaaldheid daarvan. Net so min as wat die Skrif nie meer bruikbaar is vir die kerklike lewe in die algemeen nie, ewe min kan die argument gevoer word dat Kerkreg die spreekwoordelike meulsteen om die nek van kerklike handelinge uitmaak. Kerk is kerk van die Woord en dit beteken dat die kerk se handelinge en besluite deur sy luister na die Woord gekenmerk word. Dit het noodwendig 'n Skriftuurlik bepaalde Kerkreg tot gevolg wat in byderwetse kerklike bestaan sodanig waardeer moet word. Bruikbare Kerkreg is die kerkordelike maatreëls waarin die stem van die Heer van die kerk gehoor word.

\section{KERKREG AS TEOLOGIESE WETENSKAP}

In navolging van Calvyn en die kerkregtelike ontwikkeling daarna is kerkreg as 'n teologiese wetenskap gesien en beoefen wat aan 'n teologiese fakulteit tuishoort (Coertzen 1991:152). Daar bestaan dus 'n onderskeid tussen die reg van die kerk as ius in sacra, teenoor die reg in die wêreld as 'n ius circa sacra. Dié onderskeid aangesien die primêre bron van die kerkreg die Woord van God is wat nie op die gebied van die juris in die burgerlike wetgewing val nie.

Daar bestaan geen twyfel oor die saak nie dat kerkreg ' $n$ teologiese wetenskap is wat in die kurrikulum van elke kerk se teologiese opleiding (kyk Coertzen 1992:166 vv; Heyns \& Jonker 1977:286 vv) neerslag vind. Vanweë die kernuitgangspunt dat die kerkreg die Skrif as primêre bron hanteer (kyk Coertzen 1991:120 vv; Pont 1981:6 vv) is dit vanselfsprekend dat die kerkreg noodwendig van die resultate van die Ou- en Nuwe Testamentiese wetenskappe gebruik sal maak in sy soeke hoe die reg daar behoort uit te sien (ius constituendum), maar verder ook sal put uit die Kerkgeskiedenis in sy vasstelling van die reg soos dit geformuleer is in die verlede (ius constitutum). Vanweë die noue relasie tussen Skrif, belydenis en kerkorde is die Dogmatiek onontbeerlik, asook die Praktiese Teologie as die wetenskap wat hom besig hou met die erediens en die kerklike praktyk. 
In die lig van die verknooptheid aan die verskillende vakgebiede van die teologie kan gestel word dat die kerkreg hom besig hou met die omskrywing van 'n Bybels-gefundeerde ekklesiologie, maar dit doen en verwoord op ' $n$ besondere manier naamlik 'n in regsreëls vertaalde ekklesiologie (Dingemens [1988]:207). Waarskynlik is dit juis die vorm naamlik, die kerkorde waarin die kerkreg in kerke ter sprake kom wat vir sommige aanleiding gee om veral in die huidige bestel die kerkorde, en in besonder die kerklike reg as 'n onbuigsame norm te beleef wat rigied soos juridiese wetgewing hanteer moet word, of anders met rus gelaat word aangesien die kerk, anders as die burgerlike wetgewer, nie oor die ius gladii beskik om wette af te dwing nie (Plomp 1969:73).

Verder mag dit wees dat die kritiek van die Duitse regshistorikus Rudolph Sohm (1841-1917) wat sedert 1887 in Leipzig werksaam was, in 'n sekere sin herleef. Sohm het die invoering van Kerkreg in die kerk as deel van die sondeval van die kerk bestempel daar hy spanning poneer tussen kerk en reg (Nauta 1961:212; Pont 1981:6; Coertzen 1991:12). Moontlik het die Kerkreg in die byderwetse tye waarin kerke van Reformatoriese oorsprong hulle bevind vereng tot die kerkorde as bundel wat gepas bevind word of nie, terwyl die neiging bestaan om die verhouding tussen predikant en gemeente deur bepaalde komponente van die burgerlike wetgewing te vervang, met besondere verwysing na die Wet op Arbeidsverhoudinge.

\section{KERKREG IN MEER RESENTE KONTEKS}

Bybelse teologie kan in 'n sekere sin beskryf word as 'n pendeling tussen die objektiewe en subjektiewe. Dit beteken hoe meer optimisties oor die objektiewe, oor God en sy groot dade soos aan ons in sy Woord geopenbaar word gedink en daarop klem gelê word, hoe meer pessimisties word die vooruitsig van die mens wat onder die indruk verkeer dat hy mondig en selfstandig is, en rasioneel en eiesinnig na aanleiding van eie navorsing meen om oor die waarheid te beskik.

In die kerklike reg is daar ook 'n parallel wat neerkom op 'n pendeling tussen horisontaal en vertikaal. Die vaste belydenis en uitgangspunt dat die Reformatoriese kerklike reg uiting wil gee aan die Hoof- en Heerskap van Christus, loop noodwendig daarop uit dat die kerkregtelike struktuur wat daarop volg, horisontaal van aard is. Dit het prinsipiële betekenis vir die kerk met besondere verwysing na die verhouding tussen plaaslike gemeente en sinode, of kerkraads- en sinodale vergadering. Daarom is klassikale- of ringsvergaderings, streeks- of algemene sinodes of vergaderings nie hoër vergaderings nie maar meerdere- of bykomende vergaderings. In die 


\section{Kerkreg? Die plek van Kerkreg en Kerkregering}

kerkregtelike verlede het die neiging om die struktuur vertikaal te wil plaas, reëlmatig sy verskyning gemaak. Dit kan as die kollegiale neiging in die kerklike reg tipeer word en dit is juis sinodale strukture wat maklik hieraan ten prooi val. Anders gestel kom dit daarop neer dat die neiging bestaan om die bokant van die kerk te wil ontdek, wat noodwendig daarop neerkom dat die swaartepunt van die kerk waar die Woord verkondig en sakramente bedien word, menslik gesproke, as die onderkant van die kerk gesien en waardeer moet word.

Kollegiaal, en kollegialisme as die kerkregtelike sisteem wat op Duitse bodem ontstaan het moet vir die argument onderskei word (kyk Pont 1991:110-128), en staan nie op dieselfde noemer nie. Die kollegiale vorm van kerkregering word sterk deur die verenigingsreg bepaal waarin die kerk as 'n vennootskap gesien word waar die meerderheid (sinode) oor die minderheid (gemeente) regeer en verteenwoordiging, asook spreek- en stemreg as van wesenlike waarde geag word (kyk Pont [1970]). 'n Voorbeeld hiervan is die Algemeen Reglement van 1816, en die Kerkorde van De Mist van 1804 aan die Kaap (kyk Pont 1991).

Waarskynlik is dit te wyte aan die suigkrag van die kant van die burgerlike regering waar leierskap, meerderhede, stemreg en bestuur as van deurslaggewende betekenis beskou word. In dié verband wil die kerk ook al meer soos 'n verskyning uit die korporatiewe wêreld lyk met 'n sogenaamde korporatiewe identiteit (Buitendag 2003). Hoe meer die strukture van die burgerlike owerheid, -wetgewing en die korporatiewe wêreld waarin die kerk hom bevind benut word, hoe groter is die neiging om die Reformatoriese kerklike reg en wat dit in kerkregtelike sin verwoord, as agterhaald te beskou.

\section{DIE PLEK VAN KERKREG EN KERKREGERING?}

Kerke van Reformatoriese oorsprong en belydenis maak groot erns daarmee dat die Bybel norm en rigsnoer van die kerklike lewe uitmaak. Kerkwees in historiese en toekomstige verband kom daarop neer om kerk van die Woord te wees, die sola Scriptura uitgangspunt, een van die mees basiese erfenisse uit die Hervorming, In die uiteensetting van die agtergronde van die Reformatoriese kerklike reg word noodwendig gekom tot die noue relasie tussen Skrif, belydenis en kerklike orde wat beteken dat die kerkreg soos verwoord in die kerklike orde van elke kerk vanselfsprekend nie los staan van die Skrif en die belydenisskrifte nie. Dit het nog nooit beteken dat die Skrif oor 'n pasklaar kerklike orde beskik nie, net so min as wat formuliere direk uit die Skrif afgelees word. Maar die ander uiterste dat by implikasie gewerk word met 'n kerklike orde wat niks meer is as die konstitusie van 'n vereniging wat 
gewoon deur die meerderheid aanvaar is, blyk eweneens onbruikbaar. 'n Kerk wat die Woord van God as rigsnoer aanvaar vir die kerklike lewe, moet ook sy handelinge daarvolgens laat bepaal.

Kerk van die Woord impliseer noodwendig bepaalde voor die hand liggende uitgangspunte wat steeds net so belangrik gebly het as in die kerklike lewe in Genève in die tyd van Calvyn. Die mening dat Reformatoriese kerkreg in die byderwetse tyd neerkom op 'n poging om alles na Genève te wil terugvoer dui op 'n opvallende gebrek aan insig. Verbondenheid aan die Woord van God vir 'n kerk van die Woord in die wêreld waar hy sy dienswerk moet verrig, gee op ordelike wyse uiting aan die Skriftuurlike bepaaldheid van sy handelinge. Eweneens kan moeilik anders oor ampsdraers gedink word, veral dienaars van die Woord, as geroepe ampsdraers wat bereid is om al hulle tyd en aandag aan die dienswerk te wy wat eie aan die amp is. Dat ekonomiese omstandighede onder andere kerke noop om ander bykomende besluite te neem mag waar wees, maar kan nie die Skriftuurlike uitgangspunte vervang nie. Kerk van die Woord waar die kerklike lewe ordelik verloop, is ook 'n kerk waar kerklike dissipline toegepas word en nie beteken elkeen maak wat hy wil nie. Dit sou die besluite van kerklike vergaderings buitendien nutteloos maak. Die draagkrag van die opening van kerklike vergaderings wat met Skriflesing en gebed geopen word, kan moeilik oorskat word. Daarom het die kerk nie leiers wat met mandate van die groter geheel die kerk bestuur nie, maar toegewyde ampsdraers wat diensbaar is in die wingerd van die Hoof en Heer van die kerk. Noordmans het dit gesê: die voorwaarde van kerklike optrede is kerklike denke.

Die vraag is ter sprake na die kerklike reg in die huidige kerklike lewe? Die mening word geboekstaaf, veral op grond van die eie Kerk, dat kerkreg teruggerol en vereng het tot die belangstelling van enkeles. Daarnaas word 'n reglementele kerklike reg veral op sinodale vlak beoefen met die Kerkorde in die hand, waar dit hoofsaaklik gaan oor die bruikbaarheid van bepalings al dan nie. Dit is rampspoedig vir die kerkreg as toegelaat word dat die kerklike orde 'n reglementebundel word waar die relasie tussen Skrif, belydenis en kerklike orde onderwaardeer word.

Die mening mag ook bestaan dat dit genoeg is dat Kerkreg in enkele lesings aan teologiese fakulteite aandag kry waarskynlik in navolging van die verlede. Die bedoeling van teologiese opleiding is sekerlik dat bedienaars van die Woord gevorm word wat toegerus is om die kerk te dien en derhalwe ook in staat sal wees om kerkregtelik korrek op te tree. In die lig waarin Kerkreg gesien word is houdbare kerkregtelike denke en handelinge niks anders as 'n kerklike lewe waar aan die Woord uiting gegee word nie. 


\section{Kerkreg? Die plek van Kerkreg en Kerkregering}

'n Kerk van Reformatoriese oorsprong is 'n kerk van die Woord wat klem lê op die regte verstaan en hoor van die Woord, en vind gestalte in Jesus se uitspraak dat die regte hoor en verstaan van die Woord ook beteken om so te gaan doen (Lk 10:37). Kerklike reg is die wetenskap wat erns maak met die kerk se hoor en doen volgens die Woord, en kan daarom nooit vervlak word tot hoogstens 'n lastige ergernis nie.

Erns met die kerklike reg as Reformatoriese kerkreg wat in 'n kerk van die Woord beoefen word, sal noodwendig moet sorg dat die relasie tussen Skrif, belydenis en kerklike orde gehandhaaf bly. Dit is nie 'n Geneefse uiting nie, maar word op grond van die Skriftuurlike uitgangspunt van kerkreg, onafwendbaar. Soos reeds gestel is die grootste gevaar wat kerklike reg bedreig die neiging om die Christokraties bepaalde presbiteriaal-sinodale sisteem van kerkregering wat horisontaal funksioneer, vertikaal op te rig. Die mees radikale voorbeeld word in die Roomse kerklike reg gevind (kyk Van 't Spijker 1990b:301 vv; Bronkhorst 1947:247-258) wat hier met rus gelaat word en vanself spreek. Saam met die neiging om die kerklike struktuur vertikaal te sien moet ook op die reeds genoemde kollegiale moment in die Reformatoriese kerkregering gewys word waarvan die Algemeen Reglement van 1816 sprekend is en sterk deur die verenigingsreg bepaal word.

Coertzen (1991:217) maak die volgende uitspraak reeds in 1991 wat goedskiks op die toepassing en belewenis van kerklike reg in breër kerklike verband van toepassing gemaak kan word, en waarmee groot erns gemaak moet word wanneer Reformatoriese kerkreg in byderwetse konteks ter sprake is:

Tot vandag toe gebeur dit byvoorbeeld dat 'n Kerkorde soos die van dié Ned. Geref. Kerk wat Gereformeerd wil wees dikwels in 'n kollegialistiese sin verstaan en hanteer word: wanneer die kerk byvoorbeeld as 'n blote vereniging van mense beskou word en die besluitnemingsproses as een waar die demokratiese meerderheid deurslaggewend is. Dit lê klaarblyklik in die aard van die Kollegialisme om gebruik te maak van bestaande vorme maar hulle op 'n subtiele manier van ander inhoude te voorsien.

\section{SLOTSOM}

Inderdaad, wat is die plek van Kerkreg in die hedendaagse kerklike lewe? Dit is 'n belangrike vraag, maar 'n tweede vraag. Die primêre vraag is nie na die plek van Kerkreg in die kerk nie, maar na die gesag van die Woord van God. Erns met die Skrif plaas noodwendig Kerkreg op die kerklike tafel wat uiting gee aan die eerbiedige luister na die Skrif. Kerkreg is onvervangbaar 
aangesien die kerk ook uit mense bestaan wat saam besin onder leiding van God se Gees op grond van sy Woord oor die optrede van die kerk na binne en na buite. Die taak van die kerk hou nie op nie, selfs al word die huidige meteen opgehef gaan die praktyk steeds voort. Die waarde van Calvyn lê daarin dat hy die verband tussen die Woord en die kerklike lewe (orde) aangedui het wat onverhandelbaar is en noodwendig voortgesette kerkregtelike besinning in die vooruitsig stel. Die beoefening van Kerkreg kan dus nie net beperk bly tot enkele belangstellendes nie. Beoefening van die Kerkreg veronderstel egter 'n bepaalde hermeneutiese konteks waarin die verlede ook verdiskonteer moet word. Van de Beek ([1988]:62) noem dit 'n hermeneutiese driehoek wat vorm tussen Skrif, kerkordelike maatreël en die hedendaagse situasie waarin die aangeleentheid toegepas moet word.

Kerkreg beteken nie om maar net Pretoria soos Genève (by wyse van spreke) te wil inklee nie. Maar Kerkreg volgens die Woord wat noodwendig deel van die kerk sal bly vanweë die Skriftuurlike onderbou daarvan, dui aan dat beide nie so ver uit mekaar gevind word nie. Kerkreg is deel van die kerk as geheel vanweë die feit dat die Woord van God 'n wesenlike bron en maatstaf daarvan uitmaak en behoort voortgesette aandag te geniet aan teologiese fakulteite, in sinodale werksaamhede en in gemeentes.

\section{Literatuurverwysings}

Bakhuizen van den Brink, J N 1962. Protestantse pleidooien II. Kampen: Kok. Barth, K 1964. Die Kirchliche Dogmatik, IV/2. Zürich: EVZ.

Botha, S J 1995. Kerkbegrip en kerkorde. HTS 51(3), 753-770.

Bouwman, H 1985. Gereformeerd Kerkrecht, Deel 1. Kampen: De Groot Goudriaan. Bronkhorst, A J 1947. Schrift en kerkorde. Proefskrif, Universiteit van Utrecht. Buitendag, J 2003. Die kerk se korporatiwe identiteit. HTS 59(2), 353-365.

Calvyn, J 1972. Verklaring van de Bijbel door Johannes Calvijn, 1 Korintiërs 14:40. Kampen: De Groot Goudriaan.

Calvyn, J 1992. Institusie van die Christelike godsdiens, Boek IV. Potchefstroom: CJBF.

Coertzen, P 1991. Gepas en ordelik. Pretoria: RGN-Uitgewers.

Cottret, B 2005. Calvijn Biografie. Kampen: Kok.

De Jongh, J 1911. De voorbereiding en constitueering van het Kerkverband der Nederlandsche Gereformeerde Kerken in de zestiende eeuw. Proefskrif, Vrije Universiteit van Amsterdam.

Dingemans, G D J [1988]. Kerkorde als ecclesiologisch vormgeving, in Van 't Spijker, W \& Van Drimmelen, L C (red), Inleiding tot de studie van het Kerkrecht, 207220. Kampen: Kok.

Dreyer, Y 2006. Postmoderne kerk-wees in die lig van publieke teologie - eenheid en verskeidenheid. HTS 62(4), 1311-1335. 


\section{Kerkreg? Die plek van Kerkreg en Kerkregering}

Haitjema, Th L 1925. Calvijn en de oorsprongen van het Nederlandsche Gereformeerde Kerkrecht, in Goslinga, $\mathrm{G}$ et al (red), Lustrumbundel, Christendom en Historie, 183-212. Amsterdam: Holland.

Heyns, J A \& Jonker, W D 1977. Op weg met die teologie. Pretoria: NG Kerkboekhandel.

Hooijer, C 1846. Kerkelijke wetten voor de Hervormden in het Koningrijk der Nederlanden. Zalt-Bommel: Noman \& Zoon.

Kersten, G H 1980. Kerkelijk handboekje. Utrecht: De Banier.

Kleynhans, E P J 1982. Gereformeerde Kerkreg, Deel 1. Pretoria: NG Kerkboekhandel.

Milner, B C 1970. Calvin's doctrine of the church. Leiden: Brill.

Müller, E F K 1903. Die bekenntnisschriften der reformierten Kirche. Leipzig: Deichert.

Nauta, D 1960. Presbyteriaal-Synodale stelsel, in Grosheide, F W \& Van Itterzon, G P (red), Christelijke Encyclopedie, Deel V, 502-503. Kampen: Kok.

Nauta, D 1961. Sohm in Grosheide, F W \& Van Itterzon, G P (red), Christelijke Encyclopedie, Deel VI, 212-213. Kampen: Kok.

Noordmans, O 1984. Verzamelde werken, V. Kampen: Kok.

Noordmans, O 1990. Verzamelde werken, VIII. Kampen: Kok.

Oostenbrink-Evers, H 2000. Beginselen en achtergrond van de Kerkorde van 1951 van de Nederlandse Hervormde Kerk. Zoetermeer: Boekencentrum.

Plomp, J 1969. De kerkelijke tucht bij Calvijn. Proefskrif, Vrije Universiteit van Amsterdam.

Plomp, J 1971. De Kerkorde van Emden, in Nauta, D et al (red), De Synode van Emden 1571-1971, 88-121. Kampen: Kok.

Pont, A D 1970. Die vermindering van die ledetal van die Algemene Kerkvergadering. HTS 26(1\&2), 118-145.

Pont, A D 1981. Die historiese agtergronde van ons kerklike reg, Deel 1. Pretoria: HAUM.

Post, J J H 2003. Een sikkel in een vreemde oogst? De juridische verhouding tussen hervormde gemeenten en de Nederlands Hervormde Kerk in het bijzonder bij kerkfusie. Proefskrif, Vrije Universiteit van Amsterdam.

Reid, J K S (ed) 1954. The Library of Christian classics, vol XXII: Calvin: theological treatises. Philadelphia, PA: Westminster.

Smit, C J 1984. God se orde vir sy kerk. Pretoria: NG Kerkboekhandel.

Spoelstra, B 1989. Gereformeerde Kerkreg en kerkregering. Pretoria: BUO/PU vir $\mathrm{CHO}$.

Storm, J M G. Werkgroep Kerkgeskiedenis en Kerkreg, Brief gedateer 24 April 2007.

Van de Beek, A 1988. Hermeneutiek van het Kerkrecht, in Van 't Spijker, W \& Van Drimmelen, L C (red), Inleiding tot de studie van het Kerkrecht, 59-72. Kampen: Kok.

Van den Heuvel, P (red) 2004. De toelichting op de kerkorde van de Protestantse Kerk in Nederland. Zoetermeer: Boekencentrum.

Van der Linde, G P L 1965. Die grondbeginsels van die presbiteriale kerkregeringstelsel. Potchefstroom: Pro Rege.

Van der Linde, S 1971. Van Wezel (1568) naar Emden (1571). Theologia Reformata, XIV, 181-198. 
Van der Walt, J J 1976. Christus as Hoof van die kerk en die presbiteriale kerkregering, Potchefstroom: Pro Rege.

Van 't Spijker, W 1990. Het presbyteriale-synodale stelsel, in Van 't Spijker, W et al (red) De Kerk, 326-337. Kampen: De Groot Goudriaan.

Van 't Spijker, W 1990b. Episcopalisme, in Van 't Spijker W et al (red), De Kerk, 301312. Kampen: De Groot Goudriaan.

Van Wyk, B J 1989. Die Presbiteriaal-sinodale kerkbegrip met besondere verwysing na die Kerkwet van die Nederduitsch Hervormde Kerk van Afrika. DDproefskrif, Universiteit van Afrika.

Van Wyk, B J 2004. Die Kerkorde en die kerklike reg in die Nederduitsch Hervormde Kerk van Afrika aan die hand van die Presbiteriaal-sinodale kerkbegrip. PhDproefskrif, Universiteit van Pretoria. 